guarding the financial interests of both themselves and their customers. The educational campaign will be extended through the holding of beat meetings throughout the county, at which some of the most successful local men may tell what they have found from actual experience to be most feasible and profitable in that particular community. By coöperative action, the necessary agricultural and economic readjustments can be made gradually, but at a rate that will offset the increasing capacity of the weevil for damage, which usually reaches a maximum about the third year after the infestation begins. In this way the total value of farm products can at least be maintained, better agricultural practices inaugurated and prosperity most certainly increased. Labor must be retained, bad accounts avoided and foreclosures of mortgages prevented, also, if success is to be achieved in this campaign.

At its recent state convention the Alabama Bankers' Association unanimously and enthusiastically voted to support this movement and work along this line is a leading feature in the work of that association this year. There is no measuring the possible good that may result from this movement. By it the value of the Farm Demonstration Work, for instance, can probably be doubled in one year with very slight additional expenditures. Much, however, depends upon local initiative and leadership, and the leaders in this movement must have a clear vision as to the possibilities of Southern agriculture under the application of the best methods of farming with diversified crops and increased stock. They must realize the full capacity for damage of the boll weevil and must be willing to face the situation with frankness, but with unflinching courage and faith in their ability to make the fight against the weevil successfully.

President P. J. Parrotr: This is certainly one of the most interesting phases of committee work on a large scale. If there is no discussion we will now take up the paper by Mr. George A. Dean on "Grasshopper Control Work in Western Kansas."

\title{
GRASSHOPPER CONTROL WORK IN WESTERN KANSAS
}

By Geo. A. Dean, Entomologist, Kansas State Apricultural College and Experiment Slation

For several years the native grasshoppers, the most common species of which were Melanoplus differentialis, Melanoplus bivitattus and Melanoplus atlanis, had steadily increased in numbers over the western counties of Kansas, and in many of the counties did a large amount of damage to the crops. In the early fall of 1912 , conditions were 
very favorable for the females to oviposit, and the dry, mild winter which followed enabled fully 90 per cent of the eggs to pass the winter uninjured. In the spring the investigations of the field agents of the Department of Entomology of the Kansas State Agricultural College and Experiment Station and the district farm demonstration agents, ${ }^{1}$ together with a large number of reports from various parts of the state, showed that enormous numbers of the hoppers were hatching out and that it was very probable that the farmers of western Kansas would experience the most serious outbreak of grasshoppers known in that part of the state, unless prompt and vigorous efforts were made to put in operation methods effective in destroying them.

Three years ago the Department of Entomology realizing that not only were the grasshoppers increasing in alarming numbers, but also that they would be doing enormous damage to the crops, stationed Mr. Francis B. Milliken, ${ }^{2}$ assistant entomologist, in the field to study the situation and develop effective methods for the control of the hoppers and demonstrate to the farmers that they could protect their crops. In this work it was found that poisoned bran mash, the hopper dozer, and poultry and young hogs were very efficient measures for the control of the grasshoppers.

Several of the recommended formulæ for the preparation of the poisoned bran mash were used, but after thoroughly testing several of the various ones, Mr. Milliken recommended the following formula as containing the quantities of the various ingredients that proved most efficient and could be most conveniently handled:

Formula:

Bran ....................................... 20 lbs.

Paris green $\ldots \ldots \ldots \ldots \ldots \ldots \ldots \ldots \ldots \ldots \ldots \ldots \ldots \ldots \ldots, 1 \mathrm{lb}$.

Syrup................................... 2 qts.

Oranges or lemons ........................... 3 fruits

Water................................... $3 \frac{1}{2}$ gals.

Preparation and distribution:

Mix the bran and Paris green thoroughly in a wash tub while dry. Squeeze the juice of the oranges or lemons into the water, and chop the remaining pulp and the peel to fine bits and add them to the water. Dissolve the syrup in the water and wet the bran and poison with the mixture, stirring at the same time so as to dampen the mash thoroughly.

1 The district farm demonstration agents are state and government men. They are farm advisers and work under the direction of the Kansas State Agricultural College.

${ }^{2} \mathrm{Mr}$. Francis B. Milliken was assistant entomologist of the Kansas Experiment Station for the two years previous to September 1, 1912, and is now with the Bureau of Entomology, United States Department of Agriculture. 
The bait when flavored with oranges or lemons was found to be not only more attractive, but also more appetizing, and thus was eaten by more of the grasshoppers.

The damp mash or bait should be sown broadcast in the infested areas early in the morning, or about the time the grasshoppers are beginning to move about from their night's rest. It should be scattered in such a manner as to cover five acres with the amount of bait made by uning the quantities of ingredients given in the above formula. Since very little of the bran mash is eaten after it becomes dry, scattering it broadenst in the morning, and very thinly, places it where the largest number will find it in the shortest time. Sowing it in this manner also makes it impossible for birds, barnyard fowls, or live stock to secure a sufficient amount of the poison to kill them. On alfalfa fields, in order to sccure the best results, the bait should be applied after $i$ crop has been removed and before the new crop has started. Inismuch as the poisoned bait does not act quickly, it will be from two to four days before the grasshoppers are found dead, and these will be more numerous in the sheltered places. It does not require much of the poison to kill them. Even a small portion from one of the poisoned flakes will be sufficient to cause death.

Last spring, early in the season the Department of Entomology sent out advance notices and circulars of warning, stating how favorable the conditions had been for the female grasshoppers to oviposit, and how the mild, dry winter had enabled fully 90 per cent of the eggs to pass the winter uninjured. This information was published in all the farm journals and nearly every daily and county newspaper in the state. Later, the department not only sent out another warning, stating that the hoppers had hatched out in enormous numbers, and that they were already seriously injuring crops, but also sent two men to demonstrate the practical methods of control. Three district farm demonstration agents were also busy in urging the farmers to prepare to fight the grasshoppers that were already devouring their crops. Many farmers, and in one place the entire county, put into operation the methods recommended and profited thereby, but the great majority either paid no attention to the warning or failed to put the methods of control in operation at the opportune time; that is, while the grasshoppers are young or are just migrating into the cultivated fields, and thus they soon found themselves facing the most serious outbreak of grasshoppers known in their part of the state. They were now compelled either to destroy the almost fully grown hoppers or allow them to completely devastate their crops, kill their orchards and destroy their shade trees. The farmers were now crying for help. Mr. G. E. Thompson, the district farm demonstration agent of Southwest Kansas, 
succeeded in getting Ford County to organize for a systematic fight. The county commissioners realizing the seriousness of the situation agreed to appropriate money out of the county funds to furnish free poisoned bran mash for every farmer in the county. The county was organized through the township trustees, every trustee being held responsible for the work in his township. The governor of the state was requested to urge upon the county commissioners of the adjoining county to coöperate in the work. Monday, July 14, was set as the "grasshopper day." The county commissioners had distributed over the entire county the following printed circular:

\section{Grasshopper Fight Next Monday}

"In view of the alarming numbers in which grasshoppers are appearing in Ford County, and the untold damage which they are causing to growing crops, the board of county commissioners has appointed Monday, July 14, as the date on which to make a united and determined effort throughout all the townships of the county to destroy the pests as completely as possible.

"In order to enlist the help of every farmer in the county, in one big effort to exterminate the grasshoppers on that day, we have directed the trustees in every township to purchase at county expense the supplies which are nceded in his township for poisoning the grasshoppers, using the formula which the State Agricultural College has found to be most effective.

"We appeal to every farmer, every landowner and every tenant to take up this matter at once with the trustee of their township who will furnish all the supplies and have charge of the work in that township. The situation demands that we deal with this pest promptly and effectively. Please get in touch with your trustee at once by telephone or otherwise, find out where you are to go to get the materials and interest all your neighbors in the campaign.

"Get your supplies in time so that you will be ready to spread the bait early Monday morning before the grasshoppers have begun to move.

"This is one of the most serious situations Ford County has faced for several years. We must have every farmer in the field early next Monday morning it we get the best results. All that remains for the farmer to do is to go to the trustee and get the materials which the county is furnishing and spread them on the infested fields. Please give every assistance in your power.

\section{G. W. Artwern, W. J. Davies, C. R. Aten, County Commissioners."}

This summons was electric in effect. It was as if an army were moving on the country. Farmers who had stood helplessly by watching hordes of grasshoppers devour field after field and even orchards and shade trees, now assumed a fighting attitude. The plan proposed by the demonstration agent met with the approval of all. Ei ery township trustee was to call by telephone or see personally every farmer in his district and tell him where to call for his portion of the poison. Distributing points were established at four towns in the county. The poisoned bran mash used was to be made and distributed according to the plan recommended by the Department of Entomology. It was 
the poisoned bran mash that had proved so successful the two previous summers. Four days before the poison was to be distributed the writer took the field personally to conduct the campaign.

So well organized was the work, and so perfect the coöperation, credit for which should be given Mr. G. E. Thompson, the district demonstration agent, that two days before the time set as "grasshopper day" the county commissioners had the material on hand, and the township trustees had their forces marshaled and ready for the fight. Within the next three days supplies were distributed to the farmers sufficient to prepare nearly one hundred tons of poisoned bran mash. All day long hundreds of farmers came for their allotment of the material. One or two representatives from the Agricultural College or the University of Kansas were at each place to explain how to mix and distribute the poison. The Paris green and bran were mixed at the distributing stations, but the syrup, oranges and water were not to be added until it was ready to put out in the field. A printed circular describing the method of preparing the poisoned bran mash, together with the method of distribution, was given to every farmer, so if he forgot the instructions of the college men he would have the directions in the circular. The circular also described in detail the other methods of control. A county official checked out the poison at each place. A two hundred-pound allotment was given each farmer, providing, of course, he had use for that amount. Of course this amount was not sufficient for the farmer who had several hundred acres of crops to protect. However, the county officials felt that it was enough fully to demonstrate to him that the poison was efficient, and after he was convinced the hoppers could be destroyed and his crops saved, he would be willing to buy additional material for distribution over the remaining fields of his farm. Although the writer knew the poisoned bran mash had proved successful where it had been used on a small scale the two previous summers, and had persuaded the farmers and county officials that it was no experiment but just a piece of demonstration work, he could not help feeling anxious as to what the result would be. Over one thousand farmers in a single county had taken home the poison. Reporters from several of the leading daily papers were there to write up the result. Several other counties were waiting to either organize to distribute poisoned bran mash, or join in the criticism of the college. A number of persons, such as you always find when doing work of this sort, were waiting for an opportunity to severely criticise the work. Meanwhile the farmers had distributed one hundred ton of poison. Thus Ford County and all of us rested and waited. The grasshoppers ate and so ravenous were they for the poisoned bait that they even left their 
choicest green food. In two days the poison had done its work. Investigations and reports from all over the county showed that from 60 to 70 per cent of the grasshoppers had been killed by the first application. Counts made in alfalfa fields of average infestation, showed from one hundred and fifty to two hundred and fifty dead grasshoppers per square foot. In many places under a single tree there was a peck of dead hoppers, and along hedges the ground directly under the hedge was completely covered, and in some places they were actually piled up two and three deep. In other words, the results were far better than anyone could have expected.

The grasshopper control work did not stop with Ford County. It was now an easy matter to organize, and eleven other western counties followed the example of Ford County in quick succession. In each of these counties the ingredients were furnished by the county and the same method of organization was used. The results were equally as good, and in some cases better. For instance, in Pawnee County where one hundred and twelve tons of the poisoned bran mash were distributed, fully 80 per cent of the grasshoppers were killed, and in Ellis County where one hundred and sixty-eight tons were distributed, one hundred and twenty tons of which were distributed in a single day, almost 90 per cent of the grasshoppers were destroyed.

The following report of the amount of poisoned bran mash used in the grasshopper control work is taken from the reports of the county officials:

AMOUN'TS OF POISONED BRAN MASH USED

\begin{tabular}{|c|c|c|c|c|}
\hline County & $\begin{array}{l}\text { Area in } \\
\text { sq. mi. }\end{array}$ & $\begin{array}{l}\text { Amount furnished } \\
\text { by the county- } \\
\text { Tons }\end{array}$ & $\begin{array}{c}\text { Amount furnished } \\
\text { by individuals- } \\
\text { Tons }\end{array}$ & Total-Tons \\
\hline Ford $\ldots \ldots \ldots \ldots \ldots \ldots \ldots$ & 1,060 & 98 & & 98 \\
\hline 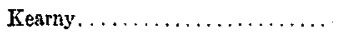 & 848 & 28 & & 28 \\
\hline Finney................... & 1,280 & 70 & & 70 \\
\hline 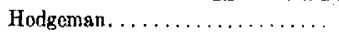 & 804 & 28 & & 28 \\
\hline Gray $\ldots \ldots \ldots \ldots \ldots \ldots \ldots$ & 852 & 60 & & 60 \\
\hline 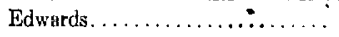 & 600 & 28 & 28 & 56 \\
\hline Pawnce........................... & 744 & 74 & 38 & 112 \\
\hline Ellis....................... & 895 & 168 & & 168 \\
\hline Trego $\ldots \ldots \ldots \ldots \ldots \ldots \ldots$ & 900 & 14 & & 14 \\
\hline Rawlins............... & 1,080 & 38 & 20 & 58 \\
\hline$S \cot t \ldots \ldots \ldots \ldots \ldots \ldots$ & 720 & 28 & & 28 \\
\hline Gove...................... & 1,080 & 54 & & 54 \\
\hline Other N. W. counties.......... & 600 & & 60 & 60 \\
\hline Other S. W. counties. & 500 & & 40 & 40 \\
\hline Total .................. & 11,963 & & & 874 \\
\hline
\end{tabular}




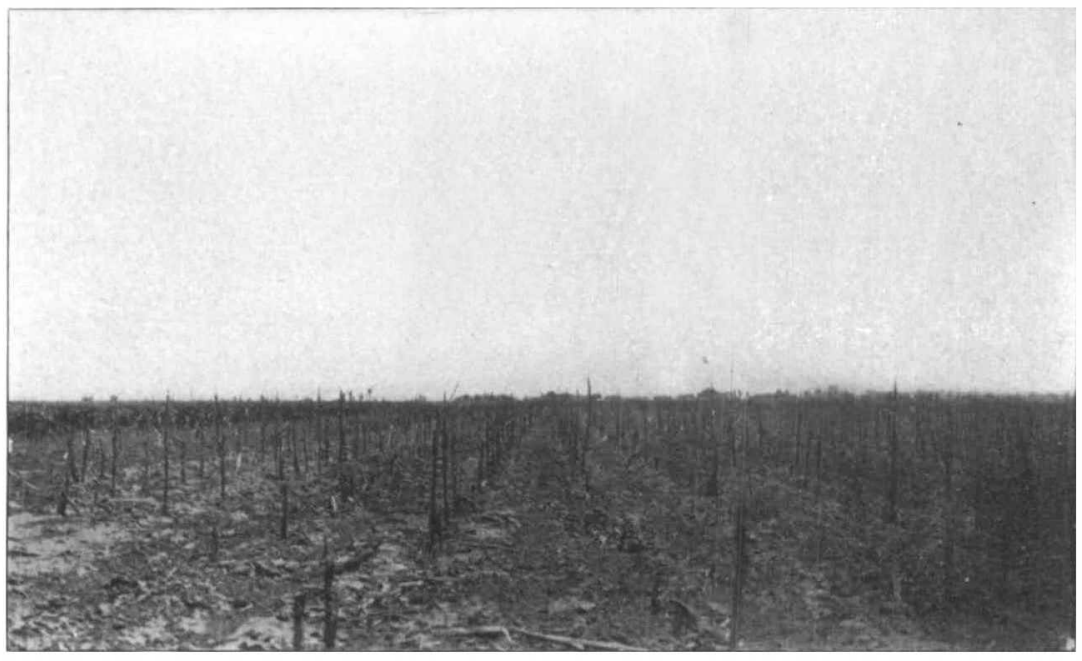

Fig. 1. Grasshoppers destroying a cornfield; only the bare stalks remain.

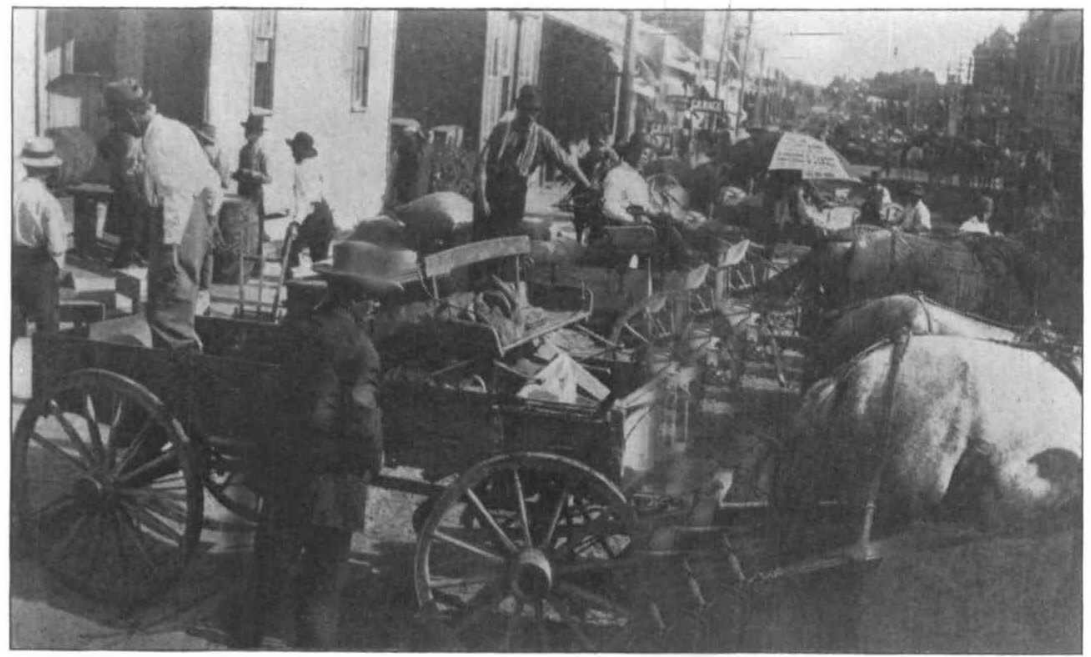

Fig. 2. Farmers getting their allotment of poisoned bran mash, Dodge City. 


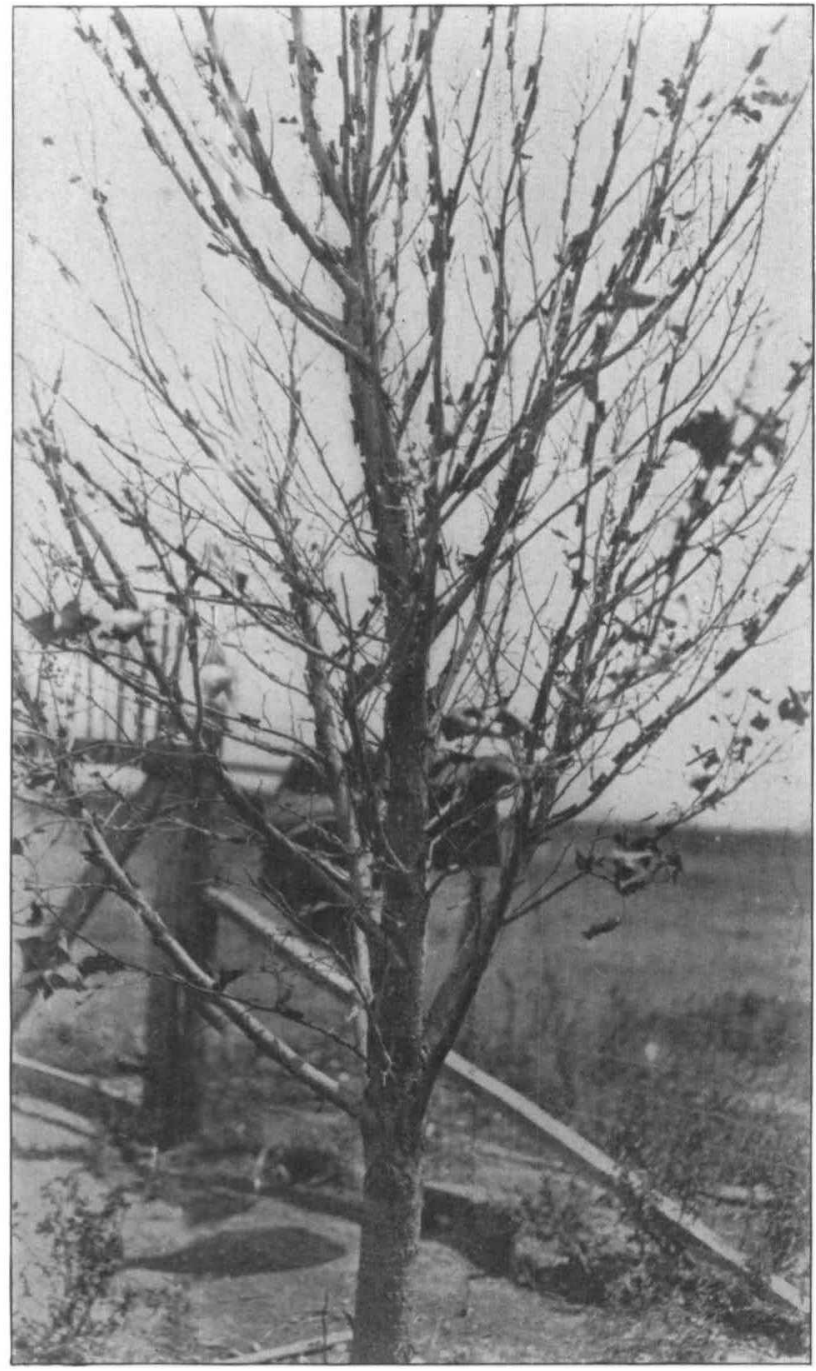

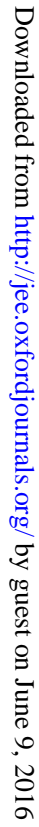

Carolina poplar defoliated by grasshoppers. 
Such excellent coöperation was had from all the farmers and county officials and so well organized was the work that it lasted only two weeks. Six representatives from the Agricultural College, threc district farm demonstration agents, one representative of the Bureau of Entomology, United States Department of Agriculture, ${ }^{1}$ and four representatives of the University of Kansas, coöperated in the work.

The entire work was an excellent example of coöperation, and demonstrated what can be done when farmers, merchants, bankers, millers, college men, farm demonstration agents, government men, and county officials get together.

Although the farmers in western Kansas experienced last summer the most serious outbreak of grasshoppers known in that part of the state, they demonstrated that they were equal to the occasion. After they were once convineed they were prompt in organizing, and by putting into operation the methods of control recommended by the Agricultural College, they were successful in destroying the grasshoppers. At the close of the season the entomologists and the farm demonstration agents made a careful examination of the grasshopper situation and were convinced that there were fewer grasshoppers in western Kansas than there had been for many years. In fact, when we consider that the farmers of western Kansas fed to their grasshoppers almost a thousand tons or two million pounds of poisoned bran mash, it is no wonder that there is a scarcity of grasshoppers. From 60 to 80 per cent of the hoppers were killed by the poisoned bran mash. The remaining grasshoppers were so left to the mercy of the parasitic and predaceous enemies that only a few of them escaped.

President Parrott: This paper has been very interesting. We have another on the same subject by Prof. S. J. Hunter, which we will have before opening the subject for discussion. [The author submitted the following in place of the verbal report. Ed.]

\section{GRASSHOPPER CONTROL IN THE SOUTHERN DIVISION OF KANSAS}

By S. J. Hurter and P. Wr. Cesassen, Eniversily of Kansas, Laurence

Seventeen years ago the first problem presented to the senior author when first he became officially associated with the University of Kansas was the native grasshopper problem in western Kansas. This

${ }^{1}$ The writer desires to acknowledge the valuable coöperation of the Bureau of Entomology, United States Department of Agriculture. Mr. Harrison Smith, assistant entomologist, United States Department of Agriculture, helped very much in organizing counties in Northwest Kansas. 